\title{
APPLYING CAVITATION TECHNIQUE TO OPTIMIZE THE SYNTHESIS OF CATFISH EPOXIDE OIL, A BIOLOGICAL COMPOUND WITH HIGH CHEMICAL ACTIVITY
}

\author{
Hong Tran Thi ${ }^{1,2,3, 凶}$, Tien Nguyen Minh $^{3}$, Quy-Diem Do ${ }^{3}$, Nhan Cao \\ Thanh $^{3}$, and Tan Phan Minh ${ }^{1}$ \\ ${ }^{1}$ Ho Chi Minh City University of Technology (HCMUT), Ho Chi Minh City, Viet Nam \\ ${ }^{2}$ Vietnam National University, Ho Chi Minh City, Viet Nam \\ ${ }^{3}$ Industrial University of Ho Chi Minh City, Ho Chi Minh City, Viet Nam \\ ${ }^{\circledR}$ Corresponding Author: 1585017@hcmut.edu.vn
}

\begin{abstract}
This study reported the synthesis of catfish epoxide oil with the assistance of the cavitation technique. The highest yield $(94.11 \%)$ of epoxidation reaction of catfish fat with hydroperoxide, acetic acid, sulfuric acid catalyst achieved at $50 \mathrm{PSi}, 45^{\circ} \mathrm{C}$, the molar ratio of $\left(\mathrm{H}_{2} \mathrm{O}_{2} / \mathrm{CH}_{3} \mathrm{COOH} /\right.$ double bonds $\left.(\mathrm{C}=\mathrm{C})\right)$ of $(3.75 / 1.25 / 1)$ in just 5 minutes. The characterization of materials and products were analyzed by FT-IR, ${ }^{1} \mathrm{H}-\mathrm{NMR},{ }^{13} \mathrm{C}-\mathrm{NMR}$ analysis. The results showed that the cavitation technique improved significantly the efficiency of the catfish epoxide oil process. The synthesis process used catfish fat feedstock, a by-product of catfish meat processing with available abundant supply. The epoxidized catfish oil product was high chemical activity and it also could be predicted as a high biodegradable compound. It could be said that the sustainability of the process is possible entirely.
\end{abstract}

Keywords: Catfish Fat, Epoxide Oil, Cavitation

RASĀYAN J. Chem., Vol. 14, No.1, 2021

\section{INTRODUCTION}

Vegetable oils and animal fats are not only substitutes for crude oils but also bio-renewable sources. ${ }^{1}$ The epoxidation reaction of unsaturated compounds in vegetable oils and animal fats created the oxirane ring compounds, which had high chemical activity. Hence, they could react to other reactants such as, compounds of alcohol, carboxylic acid and their derives to produre bio-based oils, bio-lubricants, bioplastics and other eco-friendly products. ${ }^{2}$ With the aim of searching for alternative materials for the production of bio-plastics, J. Wang et al, used epoxidation reaction to convert soybean oil to oxirane ring, which could be used as feedstock in the green plastics production. The conversion $(88.8 \%)$ of reaction reached at $50{ }^{\circ} \mathrm{C}$ and 8 hour. ${ }^{3} \mathrm{~S}$. Silviana et al, were synthesized bio-composites from ring epoxide oils (products of the epoxydation reaction of waste cooking oils and acetic peracid) and mixture of (waste cassava, bagasse powder - enhancing material for bamboo fibers features), glycecol, lemon juiceas. The observed results showed that the thermal, tensile stability of products were high. ${ }^{4} \mathrm{R}$. Turco et al, performed the opening reaction of soybean oxirane oil with 2-propanol to synthesize biobasestock, solid acid catalyst in lab-reactor. The high conversion of reaction reached at molar ratio of (alcohol/oil) of $10,80^{\circ} \mathrm{C}$ and 5 hours. The kinematic viscosity of product was improved significantly. ${ }^{5}$ In research of R.V. Sharma and partners, bio-lubricants were synthesized from canola oil by the process of two successive reactions as epoxidation and opening reaction of epoxide ring. In Amberlite IR $-120 \mathrm{H}$ catalyst, the high convertibility of two reactions was achieved at $\left(65^{\circ} \mathrm{C}, 8\right.$ hours $)$ and $\left(120{ }^{\circ} \mathrm{C}, 15\right.$ hours). Canola polyester oil had high thermal stability, high lubricity and low pour point. ${ }^{6}$ Next, A.K.R. Somidi et al, used reactions of epoxidation and ring-opening oxirane to convert vegetable oils to polyester oils. The highest conversion of epoxidation reaction reached at a molar ratio of (hydroperoxide/C=C) of $(2.25 / 1), 120^{\circ} \mathrm{C}, 1$ hour in the reactor as mechanical stirrer with the speed of $450 \mathrm{rpm}$. Properties of products were improved much more. So they could be used as bio-lubricants. ${ }^{7}$ K.A. Aissa and colleagues also used the reactions of epoxidation and carbonation to enhance the thermal stability of the vegetable oils so that they could meet the quality requirements of mineral base oils or lubricants. ${ }^{8}$ Therefore, it could be said that the epoxide ring oil compounds, synthesized from vegetable oils could be used as a substitute for fossil materials in the production of based oils, lubricants and plastics. Also, both vegetable oils derived epoxide ring compounds and their products could be expected to be green materials. 
In previous studies, the reactants could be difficult to dissolve together, so it could be said that these reactions were heterogeneous. But they were also performed in the reactor as the glass flask-magnetic stirrer or mechanical stirrer. Hence, the efficiency of reactions was limited a lot, which could be listed as high loading reactant, high energy consumption and long reaction time. On the other hand, the use of edible oils as feedstocks in bio-base oils or bio-lubricants production could be raised the global concern for the shortage of cooking oil supplies in food processing. These issues had prompted the research, finding the alternative materials resources and applying advanced reaction techniques to optimize the processes.

Recently, many studies were focusing on the application of high mixing techniques in heterogeneous reactions and the yield of the reactions has increased significantly. In the research of G. L. Maddikeri et al, used cooking oil and acetate methyl were used as reactants and their reaction they were performed on the ultrasonic agitator reactor. The observed results were shown that reaction time, reactant consumption, catalytic consumption was reduced and the reaction yield was increased when compared with the reaction performed on the reactor as a mechanical stirrer. ${ }^{9}$ S. Mohan et al, performed the esterification reaction of vegetable oils with methanol, alkali catalyst on the combined reactor of the mechanical stirrer and ultrasonic device. The results showed that the reaction yield was higher, reactant consumption and loading catalyst were lower and reaction time was shorter when compared to the reaction performed on the mechanical stirrer. ${ }^{10} \mathrm{P}$. Dhanke et el, used an ultrasonic cavitation reactor for the synthesis of biodiesel from cottonseed oil and methanol, $\mathrm{NaOH}$ catalyst. The results showed that loading catalyst and reactants, as well as reaction temperature and time, were reduced significantly and the products could meet according the ASTM standard for biodiesel. ${ }^{11}$ In the research of L.H. Chuaha and his colleagues, the reaction of waste palm oil and methanol, $\mathrm{KOH}$ catalyst was carried out on the hydrodynamic cavitation reactor. The highest reaction conversion $(98.1 \%)$ reached at a molar ratio of (waste palm oil/methanol) of (1/6), $60{ }^{\circ} \mathrm{C}$ and only 15 minutes. ${ }^{12}$ Next, T.T. Hong and partners in Ho Chi Minh City University of Technology, HCMC Vietnam National University also used the cavitation equipment as a reactor on the degum process of catfish fat with water. The optimal conditions of the process were $60 \mathrm{PSi}, 40{ }^{\circ} \mathrm{C}$ and only 3 minutes. ${ }^{13}$ To improve the efficiency of the process, I.A. Khan et al, carried out the biodiesel synthesis from Cannabis sativa L. oil and methanol, base catalysis on the hydrodynamic cavitation reactor with orifice plate type. ${ }^{14}$ Therefore it could be clear that the use of high-performance agitators as reactors for heterogeneous reactions improves the efficiency of the reactions significantly.

Vietnam was an exporter of catfish fillet with large volumes. In 2018, the harvest of catfish reached over 1.42 million Tons, up $8.4 \%$ compared to 2017. In 2020, Viet Nam is going to produce from 1.8 to 1. 9 million Tons of catfish. ${ }^{15}$ In catfish fillet processing, catfish fat could be a waste, by-product in large amounts. Every year, Vietnam could supply large amounts of catfish fat. According to previous scientific publications and scientific literature could be determined that physicochemical properties, as well as the chemical structure of vegetable oils, could be equivalent to catfish fat. ${ }^{1,13,16,17}$ Therefore, it could be confirmed that catfish fat can be used as raw materials in bio-base oil or bio-lubricants synthesis.

Researching utilizing the abundantly available catfish fat resource as feedstock for the epoxide ring oil synthesis under the assistant of cavitation technique has been determined the goal of this study. The effect of parameters on the process was studied. The characteristic of materials and products were analyzed by FT-IR, ${ }^{1} \mathrm{H}-\mathrm{NMR},{ }^{13} \mathrm{C}-\mathrm{NMR}$ analysis. The process will develop towards green chemistry.

\section{Material}

\section{EXPERIMENTAL}

Catfish fat (CFF) was supplied from Phuoc Thanh Agricultural Import Export Company Limited, Long Xuyen City, An Giang province, Viet Nam. Hydroperoxide $\left(\mathrm{H}_{2} \mathrm{O}_{2}\left(30\right.\right.$ wt.\%)), acetic acid $\left(\mathrm{CH}_{3} \mathrm{COOH}\right.$ $\left(99\right.$ wt.\%)) and sulfuric acid $\left(\mathrm{H}_{2} \mathrm{SO}_{4}(99\right.$ wt.\%)) made in Vietnam. The chemicals used in analysis meet the pure chemical standards and they were originated by Merck, Germany.

\section{Epoxidation Process of Catfish Fat Prepare Catfish Fat Feedstock}

Catfish fat was removed from mechanical impurities by vacuum filtration with a filter cloth in pore diameter of $30 \mu \mathrm{m}$. Next, catfish fat was degummed with water to remove hydrophilic impurities and collect liquid catfish fat as feedstock for the epoxidation process (presented in previous research). ${ }^{13}$ 
The cavitation reactor is an orifice plate type, 1 hole with a hole diameter of $1 \mathrm{~mm}$ and it was described in detail in Fig.-1. ${ }^{13}$

Epoxidation reaction of catfish fat performed on cavitation reactor. The surveyed parameters were pressure in $(30 \mathrm{PSi} \div 70 \mathrm{PSi})$, time in $(3$ minutes $\div 11$ minutes $)$, the temperature in $\left(25^{\circ} \mathrm{C} \div 65^{\circ} \mathrm{C}\right)$ and the molar ratio of (hydroperoxide/unsaturated compounds in fat) $\left(\mathrm{H}_{2} \mathrm{O}_{2} / \mathrm{C}=\mathrm{C}\right)$ in $(1.25 / 1 \div 6.25 / 1)$. The molar ratio of (acetic acid/ unsaturated compounds in fat) $\left(\mathrm{CH}_{3} \mathrm{COOH} / \mathrm{C}=\mathrm{C}\right)$ and loading sulfuric acid catalyst was fixed at (1.25/1) and 1.25 (v.\% (acetic acid and hydroperoxide)) respectively. ${ }^{6,16,18,19}$

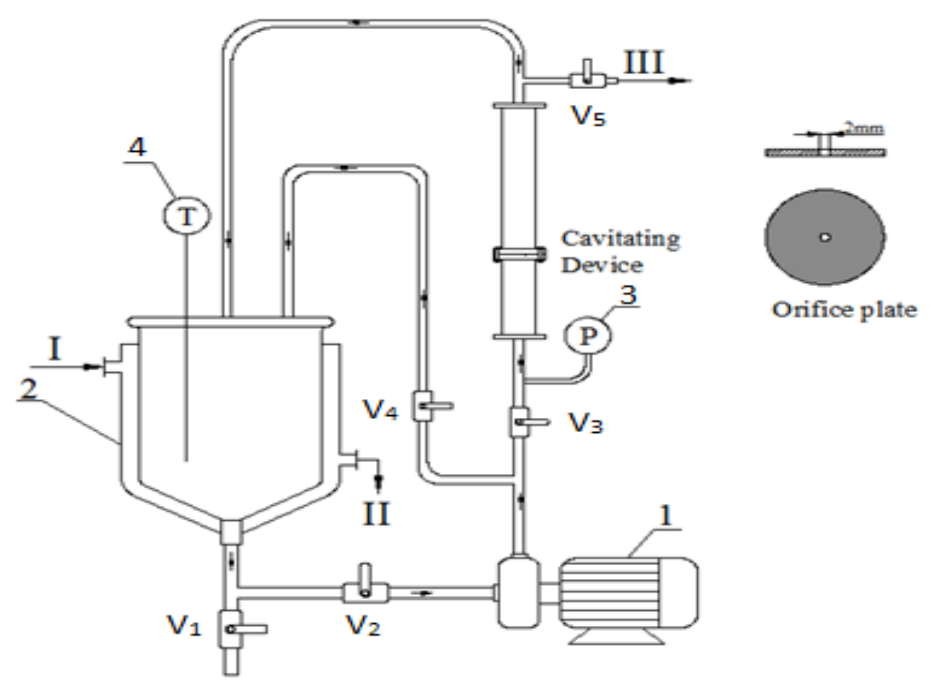

Where:

1- Vacuum pump

2- Tank

3- Pressure measuring device

4- Thermometer

$\mathrm{V}_{1}, \mathrm{~V}_{2}, \mathrm{~V}_{3}, \mathrm{~V}_{4}, \mathrm{~V}_{5}$ - Valve

I, II cooling water in / out

III- Sample line

Fig.-1: Cavitation Device ${ }^{13}$

The operation of catfish fat epoxidation process on cavitation reactor was showed follow as:

Firstly, check the entire system to make sure that, the cavitation system was clean and dry. All valves were closed. 2 kilograms of catfish fats were added to the Tank-2. Second, the amount of $\mathrm{H}_{2} \mathrm{O}_{2}(30$ wt.\%) and $\mathrm{H}_{2} \mathrm{SO}_{4}$ catalyst were added to the Tank- 2 slowly. Next, valve $\mathrm{V}_{2}$ and valve $\mathrm{V}_{4}$ was opened for 1 minute to allow reaction mixtures to pre-stir. Then, valve $V_{4}$ closed, valve $V_{3}$ and valve $V_{5}$ was opened simultaneously so that the reaction mixtures were pumped into the cavitation area. When pressure gauge $\mathrm{P}_{3}$ and thermometer $\mathrm{T}_{4}$ recorded the value of pressure and temperature at surveyed values, reaction time was started to count. After the reaction was completed, product mixtures were put into a separating funnel. Product mixtures were refined by washing with distilled water. Finally, epoxidized catfish oil (ECFO) product was a layer of oil on the separating funnel, it was a colorless liquid.

\section{Detection Method}

The characterization of materials and products were analyzed by FT-IR, ${ }^{1} \mathrm{H}-\mathrm{NMR},{ }^{13} \mathrm{C}-\mathrm{NMR}$ analysis. The Iodine value and the epoxy content were determined by ASTM D5994 and ASTM D1652 respectively. Other properties of samples were determined according to the ASTM and TCVN Standard.

\section{Calculation}

The yield of epoxidation reaction of catfish fat was calculated by Eq.-1, ${ }^{6,16,18}$, as follows:

$$
\mathrm{Y}=\frac{\mathrm{O}_{\mathrm{exp}}}{\mathrm{O}_{\text {theo }}} \times 100 \%
$$

Where:

Y: the yield of epoxidation reaction of catfish fat (\%)

$\mathrm{O}_{\text {exp }}$ : the weight percent of experimental oxirane oxygen (wt.\%)

$\mathrm{O}_{\text {theo }}$ : the weight percent of theory oxirane oxygen (wt.\%)

$\mathrm{O}_{\text {theo }}$ was calculated by Eq2 ${ }^{16,18}$, as follows:

$$
\mathrm{O}_{\text {theo }}=\frac{\mathrm{IV}_{0} / 2 \mathrm{~A}_{\mathrm{I}}}{100+\left(\mathrm{C}_{0} / 2 \mathrm{~A}_{\mathrm{I}}\right) \times \mathrm{A}_{\mathrm{O}}} \times \mathrm{A}_{\mathrm{O}}
$$

Where:

$\mathrm{IV}_{0}$ : Iodine value (IV) of catfish fat (gIod/100g).

$\mathrm{A}_{\mathrm{I}}=126.9$ : Iodine molecular weight $(\mathrm{dvC})$

SYNTHESIS OF CATFISH EPOXIDE OIL 
$\mathrm{A}_{\mathrm{O}}=16$ : oxygen molecular weight $(\mathrm{dvC})$

According to ASTM D1652, $\mathrm{O}_{\exp }$ was calculated by Eq.-3, as follows:

$$
O_{\text {exp }}=\frac{16}{43} E
$$

E: weight percent epoxide of ECFO (wt.\%). E was calculated by Eq.-4 , as follows:

$$
\mathrm{E}=\frac{\mathrm{V}}{\mathrm{w}} \times \mathrm{C} \times 4.3
$$

Hereby:

$\mathrm{V}$ : Titration volume of $\mathrm{HClO}_{4}(\mathrm{~mL})$

$\mathrm{C}$ : Concentration of $\mathrm{HClO}_{4}(\mathrm{~N})$

$\mathrm{w}$ : the weight of the sample $(\mathrm{g})$

\section{RESULTS AND DISCUSSION}

The Iodine value (IV) of catfish fat feedstock was determined by the ASTM D5554-15 and IV reached $69(\mathrm{gIod} / 100 \mathrm{~g})$. The effect of factors on the epoxidation reaction of catfish fat with $\mathrm{H}_{2} \mathrm{O}_{2}, \mathrm{CH}_{3} \mathrm{COOH}$, $\mathrm{H}_{2} \mathrm{SO}_{4}$ catalyst, carried out on the cavitation reactor were surveyed and the results were reported following as:

\section{Effect of Pressure}

Effect of pressure on the yield of catfish fat (CFF) epoxidation reaction, performed on the cavitation reactor are shown in Fig.-2. Data in Fig.-2 can be suggested that pressure is one of the most affecting factor on the yield of catfish fat epoxidation reaction, performed on the cavitation reactor. Namely, when pressure increases from $30 \mathrm{PSi}$ to $40 \mathrm{PSi}$, the yield of reaction increases from $76.67 \%$ to 84.43 $\%$ and the highest yield (94.11\%) is achieved at 50 Psi (as 10,12\%, and $11.47 \%$ ). When the cavitation system pressure increases to $60 \mathrm{PSi}$ and $70 \mathrm{PSi}$, the reaction yield of CFF epoxidation decrease slightly, from $94.11 \%$ to $92.19 \%$ and $90.81 \%$ as $2.04 \%$ and $1.5 \%$. This could be explained that increasing the pressure could lead to increasing the velocity of fluid flow through the hole of the cavitation system, which means the amount of liquid reactants passing through the cavitation zone could be increased. This could increase the amount of forming air bubbles in the reaction mixture. In the meantime, if the system pressure increased, the explosion of bubbles was also increased strongly, which could create the turbulence stirring in the reaction mixture. As a result, the phase contact of reactants increased significantly. Therefore, reaction ability was more radical and reaction yield increased. In this study, the pressure of 50 PSi could be as a chocked pressure ( $\left.\mathrm{P}_{\text {chocked }}\right)$. When the pressure of the cavitation system reached $\mathrm{P}_{\text {chocked, }}$, the flow rate could be constant, the mixing ability could be constant so the process efficiency did not increase. But at high pressure (60 PSi, $70 \mathrm{PSi}$ ), the exposure of the reactants could be agitated intensely and this could cause the decomposition of a quantity of oxirane oil products $^{20,21}$. So the reaction efficiency decreased slightly.

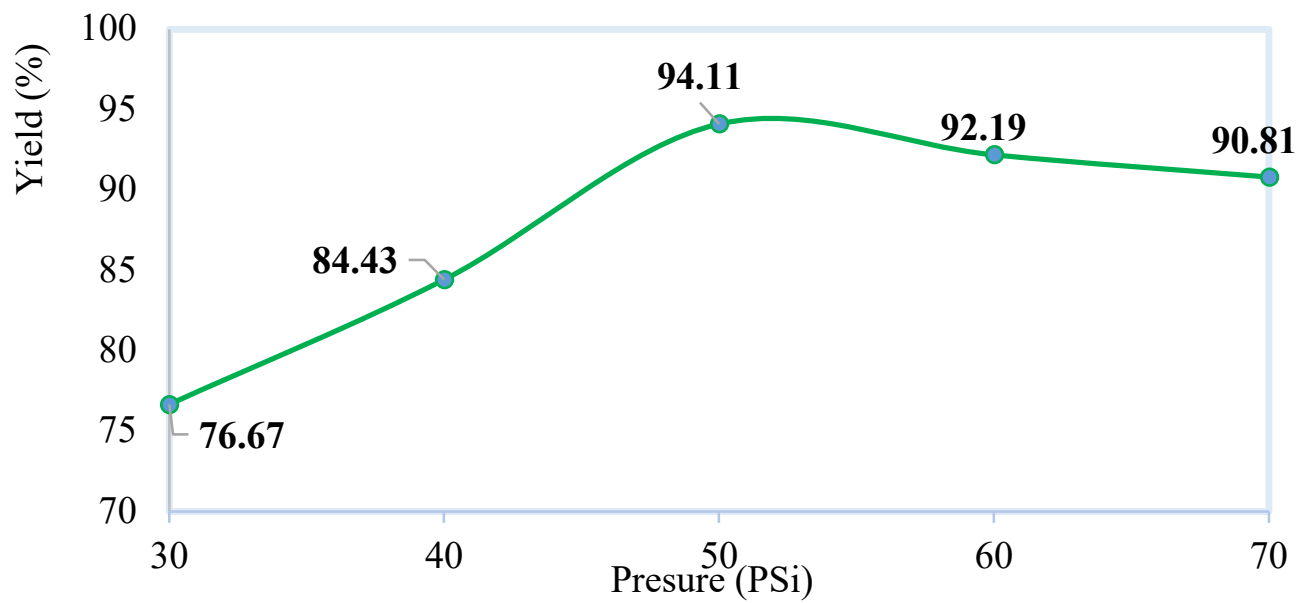

Fig.-2: The Effect of Pressure on the Yield of CFF Epoxidation Reaction, performed on the Cavitation Reactor, $\mathrm{H}_{2} \mathrm{SO}_{4}$ Catalyst. Other Factors fixed at 5 minutes, $45^{\circ} \mathrm{C}$, the Molar Ratio of $\left(\mathrm{H}_{2} \mathrm{O}_{2} / \mathrm{C}=\mathrm{C}\right)$ of $(3.75 / 1)$.

L.Maddikeri et al, used the hydrodynamic cavitation as a reactor for the interesterification reaction of waste cooking oil and methyl acetate. The authors reported the influence of pressure on the reaction yield as follows, increasing pressure in ( 2 bar $\div 4$ bar $)$ led to an increase in reaction yield. When the pressure was increased further, the reaction yield did not increase, but decreased slightly ${ }^{9}$. In fixing 
other factors, S. Bargole et al, studied the effect of pressure ( 3 bar $\div 15$ bar) on the yield of biodiesel reaction from waste cooking oil and methanol, carried out on the hydrodynamic cavitation reactor, an orifice plate type. The value of optimal pressure was defined at 7 bar. ${ }^{22}$

\section{Effect of Reaction Temperature}

As seen in Fig.-3, temperature affected greatly the efficiency of the CFF epoxidation reaction. When the temperature increased from $25^{\circ} \mathrm{C}$ to $35{ }^{\circ} \mathrm{C}$, the yield increased from $73.75 \%$ to $86.81 \%$ and the highest yield (94.11\%) (as $17.71 \%$ and $8.41 \%$ ) was achieved at $45{ }^{\circ} \mathrm{C}$. But temperature increased continuously to $55{ }^{\circ} \mathrm{C}$ and $65{ }^{\circ} \mathrm{C}$, the yield was also decreased much more (from 94.11 down to 82.98 $\%$ and $65.30 \%$, as $11.83 \%$ and $21.31 \%$ ). This could be because, when the temperature increased in the range of $\left(25^{\circ} \mathrm{C} \div 45{ }^{\circ} \mathrm{C}\right)$, the viscosity of catfish fat feedstock and chemicals decreased, in the assistance of cavitation technique could be created the intense agitation for reaction mixture. This could lead to the rapid contact of reactants and as a result, the yield of catfish fat epoxidation reaction increased significantly. However, at high temperatures $\left(55^{\circ} \mathrm{C}, 65^{\circ} \mathrm{C}\right)$ and in the presence of a sulfuric acid catalyst, an amount of catfish epoxide ring oil products could be decomposed. Hence, the yield of the reaction was also reduced. ${ }^{20,21,23}$

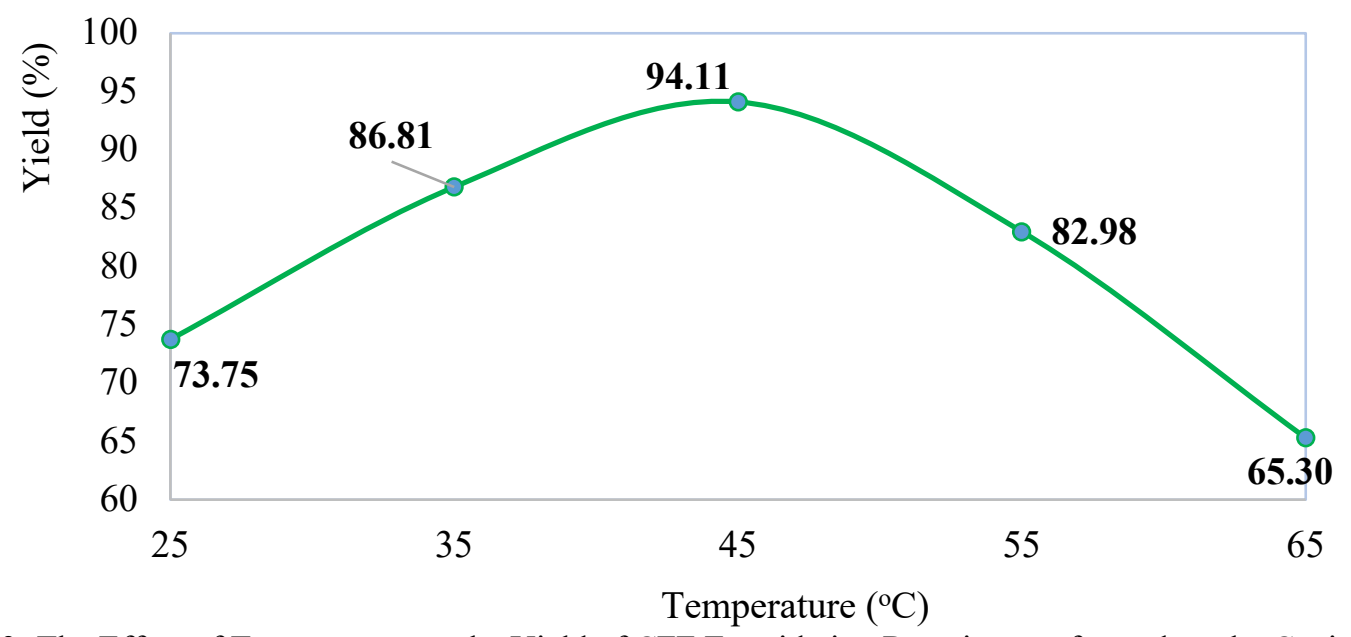

Fig.-3: The Effect of Temperature on the Yield of CFF Epoxidation Reaction, performed on the Cavitation

Reactor, $\mathrm{H}_{2} \mathrm{SO}_{4}$ Catalyst. Other Factors fixed at $50 \mathrm{PSi}, 5$ minutes, Molar Ratio of $\left(\mathrm{H}_{2} \mathrm{O}_{2} / \mathrm{C}=\mathrm{C}\right)$ of (3.75/1).

In fixing other factors, P. B. Subhedar and P. R. Gogate reported the effect of temperature on the yield of biodiesel reaction from waste cooking oil and methyl acetate, performed on the ultrasound reactor that, the temperature increased from $30{ }^{\circ} \mathrm{C}$ to $40{ }^{\circ} \mathrm{C}$ as the reaction yield also increased. However, the temperature reached $50{ }^{\circ} \mathrm{C}, 60^{\circ} \mathrm{C}$, the yield of reaction reduced clearly. ${ }^{24} \mathrm{In}$ the research of L.F. Chuaha et al, the effect of temperature on the conversion of the reaction of waste palm oil and methanol, performed on the hydrodynamic cavitation reactor were also studied and discussed similarly. In fixing other factors, the temperature increased from $50{ }^{\circ} \mathrm{C}$ to $60{ }^{\circ} \mathrm{C}$, the reaction conversion increased clearly and it was also reduced a lot when the temperature reached $65^{\circ} \mathrm{C} .{ }^{12}$

\section{Effect of Reactant Consumption}

Figure- 4 shows the effect of the molar ratio of $\left(\mathrm{H}_{2} \mathrm{O}_{2} / \mathrm{C}=\mathrm{C}\right)$ on the yield of catfish fat (CFF) epoxidation reaction, performed on the cavitation reactor. When the molar ratio of $\left(\mathrm{H}_{2} \mathrm{O}_{2} / \mathrm{C}=\mathrm{C}\right)$ increased from $1.25 / 1$ to $2.5 / 1$, the yield increased from $74.90 \%$ to $91.04 \%$ respectively. The highest yield $(94.11 \%)$ was achieved in a molar ratio of $\left(\mathrm{H}_{2} \mathrm{O}_{2} / \mathrm{C}=\mathrm{C}\right)$ of $3.75 / 1$. However, when increasing the molar ratio of $\left(\mathrm{H}_{2} \mathrm{O}_{2} / \mathrm{C}=\mathrm{C}\right)$ to $(5 / 1),(6.25 / 1)$, the reaction yield was reduced slightly to $90.27 \%, 88.35 \%$ corresponding reduction as only $4.08 \%, 6.12 \%$. This could be explained that the epoxidation reaction of CFF with hydroperoxide, acetic acid, the sulfuric acid catalyst is reversible occurs with a valid molar ratio of $\left(\mathrm{H}_{2} \mathrm{O}_{2} / \mathrm{CH}_{3} \mathrm{COOH} / \mathrm{C}=\mathrm{C}\right)$ nor $\left(\mathrm{CH}_{3} \mathrm{COOOH} / \mathrm{C}=\mathrm{C}\right)$ of $(1 / 1)$. However, $\mathrm{H}_{2} \mathrm{O}_{2}$ could be decomposed in the high temperature, $\mathrm{H}_{2} \mathrm{SO}_{4}$ catalyst, so the fact that, the molar ratio of them $>1$. When increasing the amount of reactants, forming reaction of acetic peracid from hydroperoxide and acetic acid could be increased, so the yield of epoxidation reaction could be increased accordingly. When a large amount of reactant was used, it could be lead to the excess of reactants and in the presence of catalytic sulfuric acid, plus intense agitation of the cavitation system, an amount of catfish epoxide ring SYNTHESIS OF CATFISH EPOXIDE OIL 
oils products could be joined by-reactions such as decomposition reaction, ring-opening reaction of oxirane oils. Hence, the reaction efficiency decreased. ${ }^{20,21,23}$

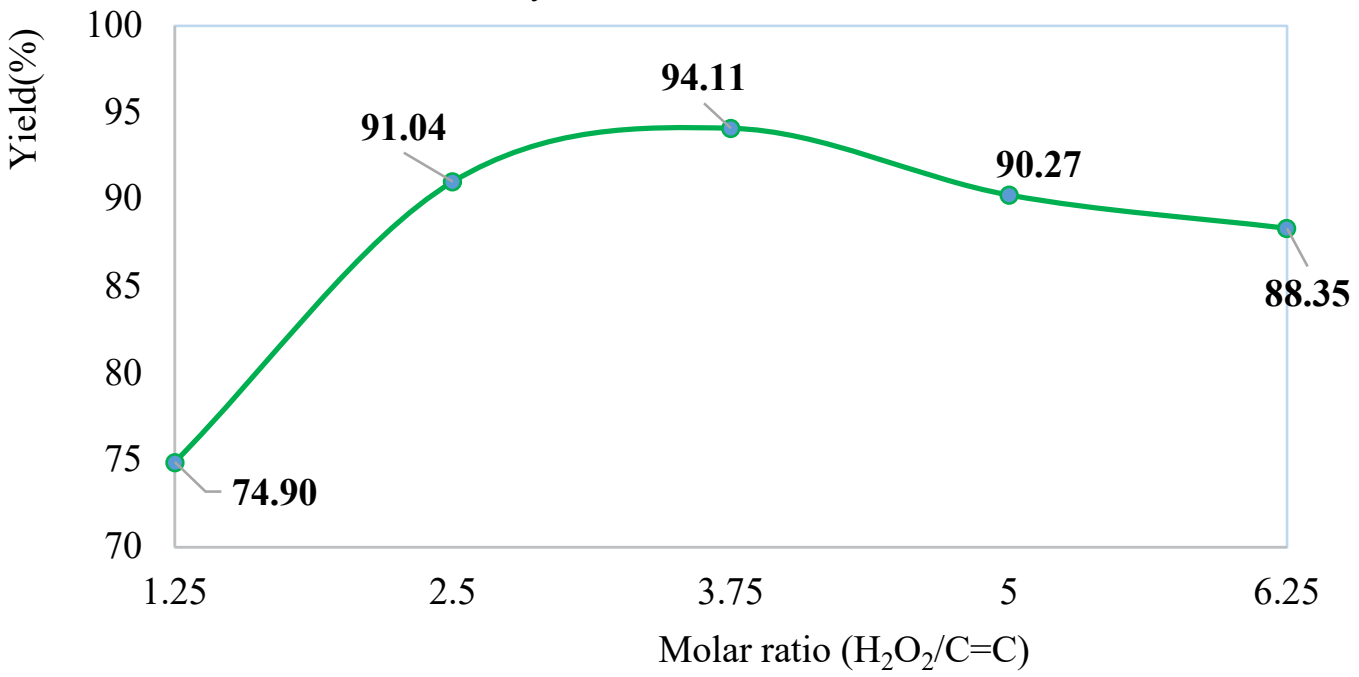

Fig.-4: Effect of the molar ratio of $\left(\mathrm{H}_{2} \mathrm{O}_{2} / \mathrm{C}=\mathrm{C}\right)$ on the yield of $\mathrm{CFF}$ epoxidation reaction, performed on the cavitation reactor, $\mathrm{H}_{2} \mathrm{SO}_{4}$ catalyst. Other factors fixed at 5 minutes, $50 \mathrm{PSi}$ and $45{ }^{\circ} \mathrm{C}$.

The effect of reactant consumption on the reaction ability also explained in previous studies of heterozygous reactions, performed on the high performance stirring reactor, ${ }^{10,11,25}$ as in the study of S. Bargole et al, authors used the statistical methods of response surface methodology to optimize the biodiesel reaction from waste cooking oil and methanol, performed on the cavitation reactor. The molar ratio of methanol/oil was surveyed in the range of $(1 / 1.96 \div 1 / 9.04)$ and optimal of molar ratio of reactants was determined at $1 / 6.8 .{ }^{22}$

\section{Effect of Reaction Time}

As seen in Fig.-5, the reaction time increases in the range of ( $3 \mathrm{~min} \div 5 \mathrm{~min}$ ), reaction yield increases correspondingly $84.54 \%, 94.11 \%$ and it is also decreased to $86.04 \%, 83.74 \%$ and $80.66 \%$ in time of 7 mins, 9 mins and 11 mins. This could be explained by the fact that the stirring capacity of the cavitation system was very strong, so a mixture of catfish epoxide ring products, sulfuric acid catalysts and other excess substances could be created stable emulsions, which could be caused difficulty in the purification stage of products. Besides, in the presence of acetic peracid, sulfuric acid catalyst, if catfish epoxide ring products were not taken out in time, it would participate secondary reactions such as the ring-opening reaction, decomposition reactions in this excess time..$^{20,21,23}$

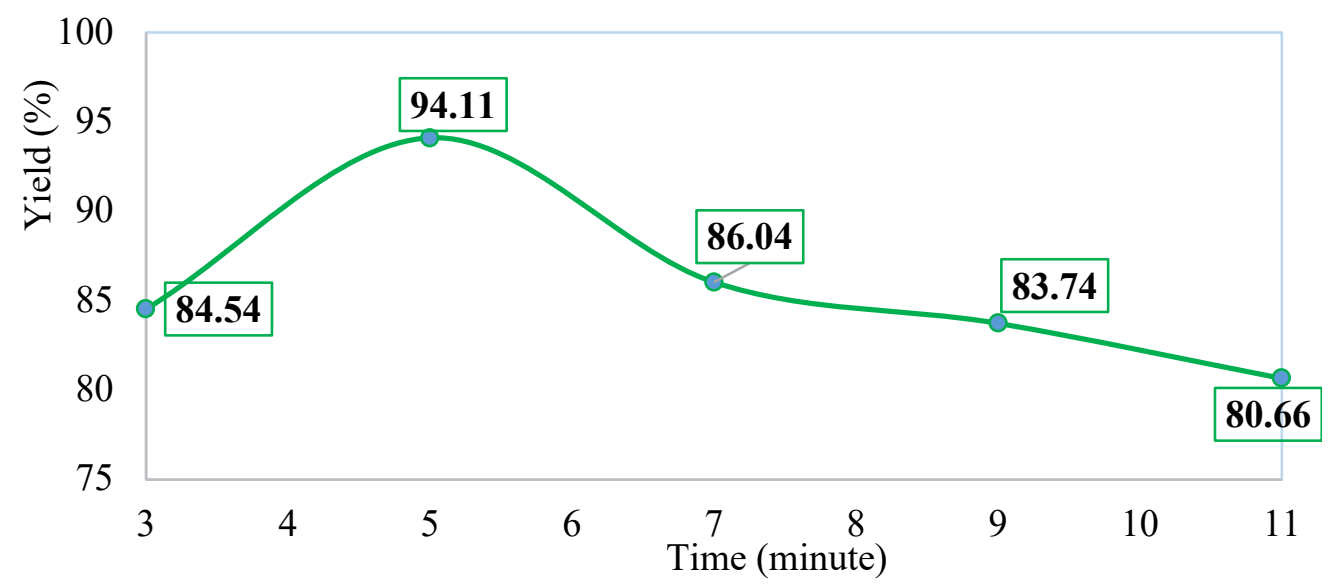

Fig.-5: The effect of reaction time on the yield of $\mathrm{CFF}$ epoxidation reaction, performed on the cavitation reactor, $\mathrm{H}_{2} \mathrm{SO}_{4}$ catalyst. Other factors fixed in $50 \mathrm{PSi}, 45^{\circ} \mathrm{C}$, the molar ratio of $\left(\mathrm{H}_{2} \mathrm{O}_{2} / \mathrm{C}=\mathrm{C}\right)$ of $(3.75 / 1)$.

The effect of time on reactivity was explained in other studies for heterogeneous reactions, performed on the reactors as advanced agitators. ${ }^{10,11,22,25} \mathrm{P}$. Dhanke et al, surveyed the effect of the molar ratio of methanol/oil in $(6 / 1 \div 15 / 1)$, the temperature in $\left(40{ }^{\circ} \mathrm{C} \div 60{ }^{\circ} \mathrm{C}\right)$, time in $(10 \mathrm{~min} \div 40 \mathrm{~min})$ on the yield of the reaction of cottonseed oil and methanol, $\mathrm{NaOH}$ catalyst, carried out on the ultrasonic cavitation SYNTHESIS OF CATFISH EPOXIDE OIL 
reactor. The optimal conditions of reaction were determined at values of $9 / 1,50{ }^{\circ} \mathrm{C}$ and 30 minutes. ${ }^{11}$ L.F. Chuaha et al, performed the reaction of waste palm oil (WPO) and methanol (Me) on hydrodynamic cavitation reactor. The effect of parameters on the reaction yield showed that when the increase of the molar ratio of (WPO/Me) to $1 / 4,1 / 6$, temperature to $50{ }^{\circ} \mathrm{C}, 60{ }^{\circ} \mathrm{C}$ and time reaction in the range of ( $3 \mathrm{~min} \div 15 \mathrm{~min}$ ), the reaction conversion increased clearly. However, these factors were increased to the corresponding values of $1 / 7,65{ }^{\circ} \mathrm{C}$ and $20 \mathrm{mins}$, the conversion of reaction did not increase more. ${ }^{12}$

In this study, the optimal conditions of catfish fat epoxidation reaction, performed on the cavitation reactor were established. The highest epoxide yield $(94.11 \%)$ was achieved at $50 \mathrm{PSi}$, the molar ratio of $\left(\mathrm{H}_{2} \mathrm{O}_{2} / \mathrm{CH}_{3} \mathrm{COOH} / \mathrm{C}=\mathrm{C}\right)$ of $(3.75 / 1.25 / 1)$, the temperature of $45^{\circ} \mathrm{C}$ and reaction time of 5 minutes. When compared with the results of other studies on vegetable oils epoxidation reactions carried out on conventional stirring reactor, it could be said that the efficiency of catfish fat epoxidation reaction with hydroperoxide, acetic acid, sulfuric acid catalyst, performed on the cavitation reactor, has increased significantly. That was the marked decrease in chemical consumption, reaction temperature, reaction time and an increase in reaction yield. L.K. Hong and colleagues reported the optimal conditions of epoxidation reaction of linoleic acid with hydroperoxide $\left(\mathrm{H}_{2} \mathrm{O}_{2}\right)$, formic acid $(\mathrm{HCOOH})$, in the acid catalyst, were $45{ }^{\circ} \mathrm{C}$, molar ratio of $(\mathrm{HCOOH} / \mathrm{C}=\mathrm{C}),\left(\mathrm{H}_{2} \mathrm{O}_{2} / \mathrm{C}=\mathrm{C}\right)$ of $(2 / 1),(12 / 1), 2$ hours and the oxirane yield reached at $80.4 \% 19$. J. Wang et al, carried out the reaction of soybean oil $(25 \mathrm{~g})$, formic acid (5 g), hydroperoxide $30 \mathrm{wt} . \%$ ( $25 \mathrm{~g})$ in choline chloride-oxalic acid dihydrate catalyst $(2 \mathrm{~g})$. The high epoxide yield $\left(83.35 \%\right.$ ) reached at $50{ }^{\circ} \mathrm{C}$ and 8 hours $^{3}$. In the research of R.V. Sharma et al, high conversion $(83.49 \%)$ of canola oil epoxidation reaction with hydroperoxide $\left(\mathrm{H}_{2} \mathrm{O}_{2}\right)$, acetic acid $\left(\mathrm{CH}_{3} \mathrm{COOH}\right)$, in Amberlite IR $-120 \mathrm{H}$ catalyst (22 wt.\% canola oil) reached a molar ratio of $\left(\mathrm{H}_{2} \mathrm{O}_{2} / \mathrm{CH}_{3} \mathrm{COOH} / \mathrm{C}=\mathrm{C}\right)$ of $(1.5 / 1 / 1), 65^{\circ} \mathrm{C}$ and 8 hours. ${ }^{6}$

\section{Characterization}

The chemical structure of materials and products were determined by FT-IR, ${ }^{1} \mathrm{H}-\mathrm{NMR},{ }^{13} \mathrm{C}-\mathrm{NMR}$ analysis. Analytical results are shown in Fig.-6, Fig.-7, Fig.-8 respectively.

\section{Results of FT-IR analysis}

FT-IR analysis of catfish fat (CFF), epoxidized catfish oil (ECFO) are shown in Fig.- 6. The FT-IR spectra of samples presents all peaks of main functional groups of them. The functional groups of ester $(\mathrm{C}=\mathrm{O})$ and eter $(\mathrm{C}-\mathrm{O}-\mathrm{C})$ show in $721.274 \mathrm{~cm}^{-1}, 724.139 \mathrm{~cm}^{-1}, 1740.44 \mathrm{~cm}^{-1}, 1743.33 \mathrm{~cm}^{-1}$ and 1102.12 $\mathrm{cm}^{-1}, 1115.62 \mathrm{~cm}^{-1}$. The $\mathrm{CH}_{3}, \mathrm{CH}_{2}$ groups present in $1373.07 \mathrm{~cm}^{-1}, 1375.00 \mathrm{~cm}^{-1}, 1461.78 \mathrm{~cm}^{-1}, 1462.74$ $\mathrm{cm}^{-1}$. The C-H groups shows in $2852.2 \mathrm{~cm}^{-1}, 2854.13 \mathrm{~cm}^{-1}$ and $2921.63 \mathrm{~cm}^{-1}, 2923.56 \mathrm{~cm}^{-1}$.

The FT-IR spectrum of CFF appears typical peaks for double bonds of Carbons in $1657.52 \mathrm{~cm}^{-1}$ and $3006.48 \mathrm{~cm}^{-1}$, these peaks do not appear in the FT-IR spectrum of ECFO and instead of appearances of specific peaks of epoxide ring in $824.42 \mathrm{~cm}^{-1}$. This could be indicated that the absence of double bonding groups of Carbons and the corresponding presence of epoxide ring groups in the chemical structure of the epoxidized catfish oil product.

Similar results of FT-IR analysis reported in other studies. In the study of R.V. Sharma and partners, the double bond $(\mathrm{C}=\mathrm{C})$ in $3007 \mathrm{~cm}^{-1}$ was showed in the FT-IR spectra of canola oil. In the FT-IR spectra of canola epoxidized oil, the peak of the double bond $(\mathrm{C}=\mathrm{C})$ did not appear but instead, peak of the epoxy ring group appeared in $831 \mathrm{~cm}^{-1} .{ }^{6}$ In the research of R. Turco et al, the peak of oxirane ring showed in $819 \mathrm{~cm}^{-1}$ in the FT-IR spectra of epoxidized soybean oil. The FT-IR spectroscopy of soybean oil showed the double bond $(\mathrm{C}=\mathrm{C})$ in $3009 \mathrm{~cm}^{-1}$ and $1651 \mathrm{~cm}^{-1}$, which did not appear in the FT-IR spectroscopy of soybean epoxidized oil. The FT-IR spectroscopy of soybean epoxidized oil reported the peak of the epoxide ring group in $826 \mathrm{~cm}^{-1} .5$

\section{Results of ${ }^{1} \mathrm{H}-\mathrm{NMR}$ Analysis}

${ }^{1} \mathrm{H}-\mathrm{NMR}$ spectra of catfish fat (CFF), epoxidized catfish oil (ECFO) are shown in Fig.-7. The ${ }^{1} \mathrm{H}-\mathrm{NMR}$ spectra of CFF show the specific proton of functional groups of the sample. The proton shift $\mathrm{CH}_{3}$ of the $\mathrm{R}$ alkyls showed at $(0.87 \mathrm{ppm} \div 0.89 \mathrm{ppm})$. $\beta-\mathrm{CH}_{2}, \alpha-\mathrm{CH}_{2}$ of alkyl $\mathrm{R}$ linked to carbonyl $(\mathrm{C}=\mathrm{O})$ showed at $(1.61 \mathrm{ppm} \div 2.09 \mathrm{ppm}),(2.29 \mathrm{ppm} \div 2.32 \mathrm{ppm})$. The proton shift $\mathrm{CH}_{2}, \mathrm{CH}$, of glycerol reported at $(4.13 \mathrm{ppm} \div 4.31 \mathrm{ppm})$. The proton shift of double bond $(\mathrm{H}-\mathrm{C}=\mathrm{C}-\mathrm{H})$ was reported at $(5.20 \mathrm{ppm} \div 5.35$ ppm). 


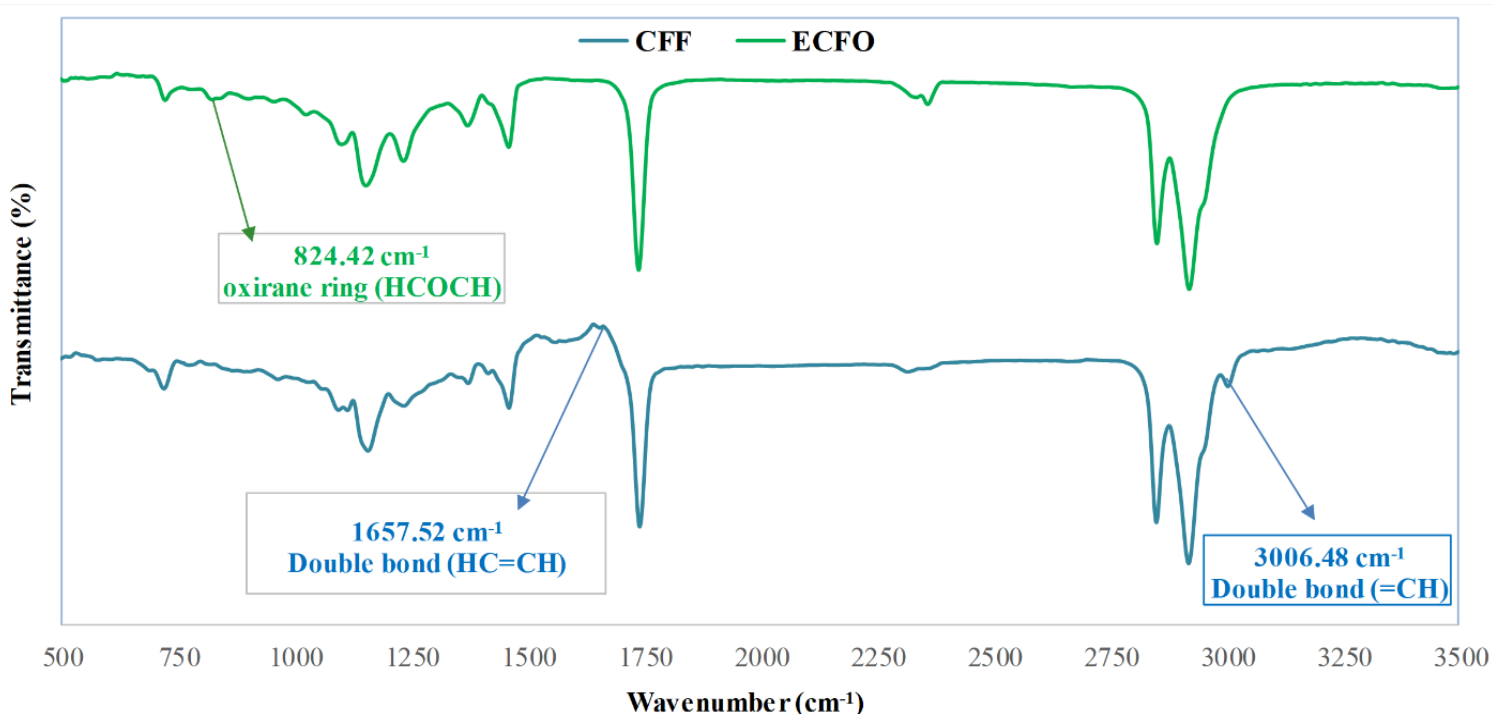

Fig.-6: FT-IR analysis of CFF, ECFO

In the ${ }^{1} \mathrm{H}-\mathrm{NMR}$ spectra of ECFO, almost all proton shifts that appeared on ${ }^{1} \mathrm{H}-\mathrm{NMR}$ spectra of CFF have presented only the absence of proton shift of $(\mathrm{HC}=\mathrm{CH})$ double bond and the corresponding appearance of the proton shifts of $\mathrm{CH}$ of epoxy oxygen $(2.89 \mathrm{ppm} \div 3.11 \mathrm{ppm}), \alpha-\mathrm{CH}_{2}$ of the epoxy group (1.62 ppm $\div 1.72 \mathrm{ppm}), \beta-\mathrm{CH}_{2}$ of the epoxy group $(1.42 \mathrm{ppm} \div 1.50 \mathrm{ppm})$. It could indicate that, double bonds $(\mathrm{HC}=\mathrm{CH})$ in $\mathrm{CFF}$ were chemically converted into epoxide rings.

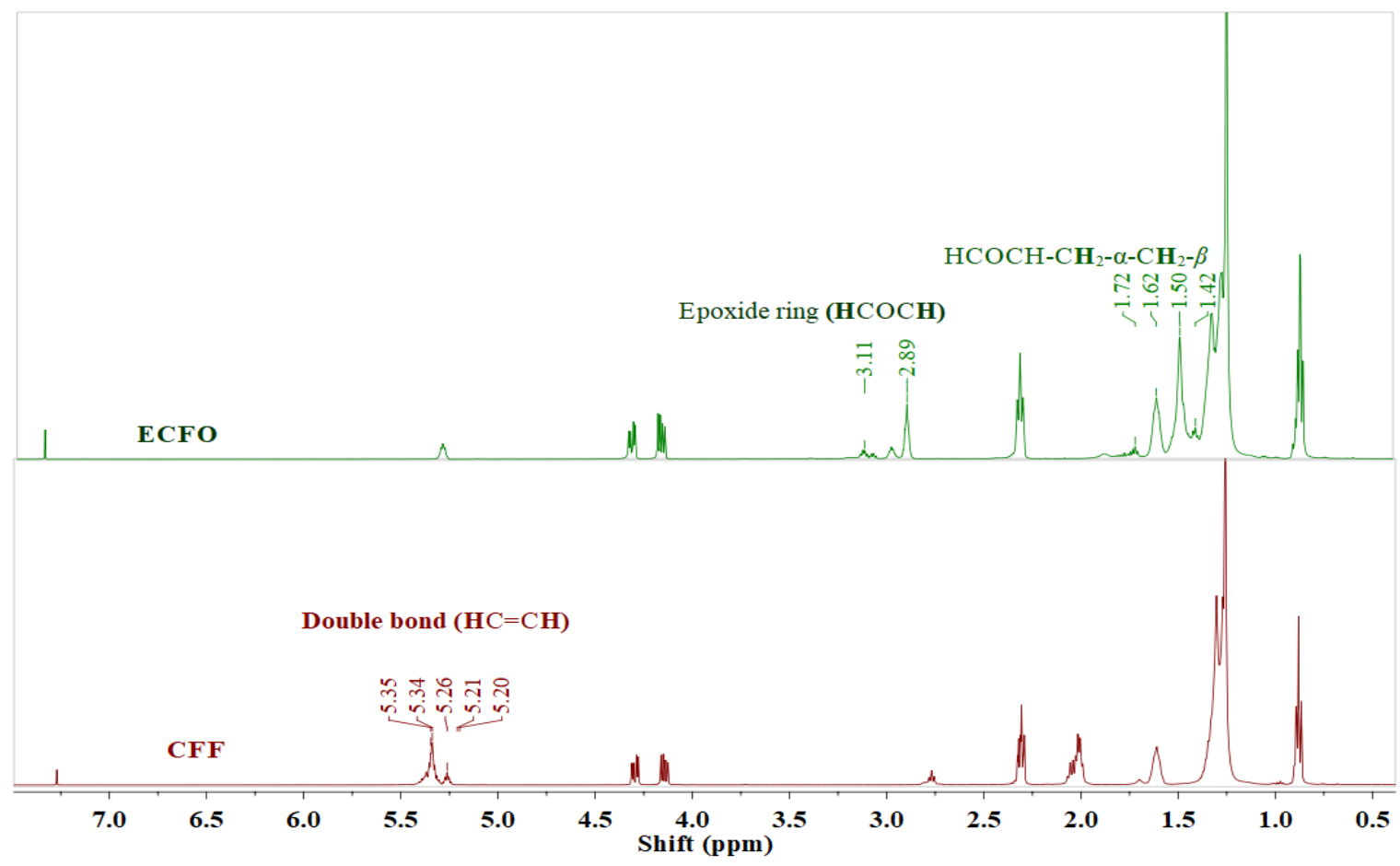

\section{Results of ${ }^{13} \mathrm{C}-\mathrm{NMR}$ Analysis}

Fig.-7: ${ }^{1} \mathrm{H}-\mathrm{NMR}$ spectra of CFF, ECFO

${ }^{13} \mathrm{C}-\mathrm{NMR}$ spectra of catfish fat (CFF), epoxidized catfish oil (ECFO) are shown in Fig.-8.The ${ }^{13} \mathrm{C}-\mathrm{NMR}$ spectra of CFF report the specific carbon shifts. The carbon shift of $\mathrm{CH}_{3}, \mathrm{CH}_{2}$ of alkyl $\mathrm{R}$ showed at $(14.03 \div 14.07 \mathrm{ppm}),(22.66 \div 31.90 \mathrm{ppm}), \mathrm{CH}_{2}$ of alkyl R linked to carbonyl showed at $(34.01 \div 34.02$ $\mathrm{ppm})$. The carbon shift of $\mathrm{CH}, \mathrm{CH}_{2}$ of glycerol bands showed at $(62.09 \div 68.91 \mathrm{ppm})$. The appearance of carbon shift at $(172.78 \mathrm{ppm} \div 173.19 \mathrm{ppm})$ in the ${ }^{13} \mathrm{C}$-NMR spectra of CFF determined the presence of carbonyl $(\mathrm{C}=\mathrm{O})$ in ester groups and the appearance of carbon shift at $(127.90 \mathrm{ppm} \div 130.18 \mathrm{ppm})$ was showed the presence of double bond $(\mathrm{C}=\mathrm{C})$ in the chemical structure of $\mathrm{CFF}$.

Except for typical carbon shift of olefinic $(\mathrm{C}=\mathrm{C})$, the ${ }^{13} \mathrm{C}-\mathrm{NMR}$ spectra of ECFO displayed most of the appeared carbon shifts on the ${ }^{13} \mathrm{C}$-NMR spectra of CFF. Furthermore, the presence of carbon shift 
at (54.12 ppm $\div 57.14 \mathrm{ppm})$ in the ${ }^{13} \mathrm{C}$-NMR spectra of ECFO demonstrated the presence of epoxide ring groups in the chemical structure of ECFO. The analytical results of methods of FT-IR, ${ }^{1} \mathrm{H}-\mathrm{NMR}$ and ${ }^{13} \mathrm{C}$-NMR were consistent. and these obtained results could be confirmed that, at the conditions that this study has established, epoxidation reaction of catfish fat with hydroperoxide, acetic acid, performed on the cavitation occurred completely.

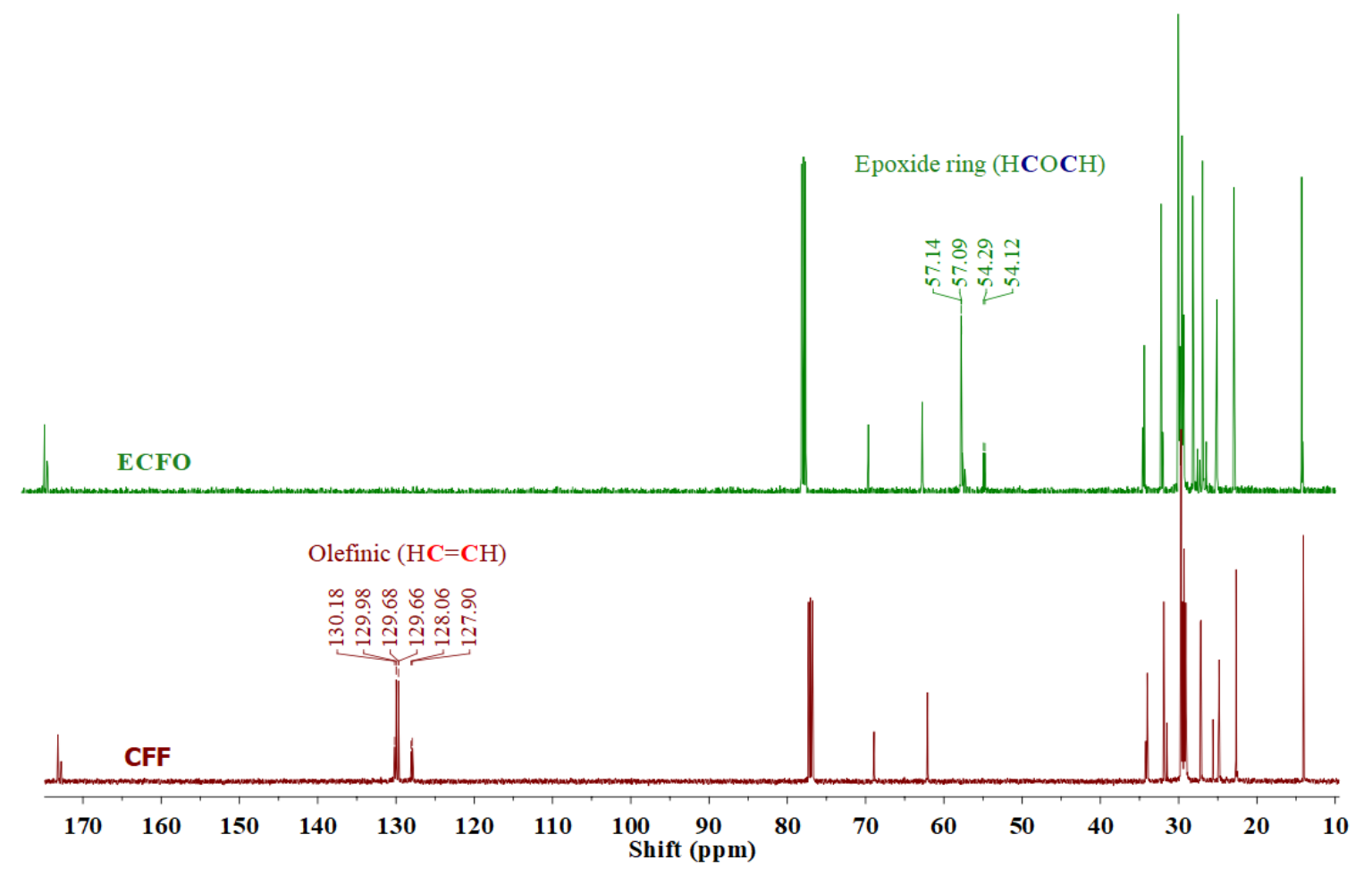

Fig.-8: ${ }^{13} \mathrm{C}-\mathrm{NMR}$ spectra of CFF, ECFO

When compared with the results of ${ }^{1} \mathrm{H}-\mathrm{NMR},{ }^{13} \mathrm{C}$-NMR analysis of vegetable oils nor vegetable oxirane ring oils in other studies showed a similarity. In the research of $\mathrm{R}$. V. Sharma and partners, the ${ }^{1} \mathrm{H}-\mathrm{NMR}$ spectra of canola oil showed the proton shift of olefinic $(\mathrm{H}-\mathrm{C}=\mathrm{C}-\mathrm{H})$ at $(5.2 \mathrm{ppm} \div 5.4 \mathrm{ppm})$, it did not appear in the ${ }^{1} \mathrm{H}-\mathrm{NMR}$ spectra of canola epoxidized oil and the corresponding appearance of proton shift of $\mathrm{CH}$ of oxirane ring, $\alpha-\mathrm{CH}_{2}$ and $\beta-\mathrm{CH}_{2}$ of oxirane ring at $(2.7 \div 3.1 \mathrm{ppm}), 1.79 \mathrm{ppm}$ and 1.6 $\mathrm{ppm}$. The ${ }^{13} \mathrm{C}$-NMR spectra of canola oil presented the carbon shift of olefinic $(\mathrm{C}=\mathrm{C})$ at $120 \mathrm{ppm}, 140$ ppm and it did not show in the ${ }^{13} \mathrm{C}-\mathrm{NMR}$ spectra of canola epoxidized oil but instead was the appearance of the carbon shift of epoxide ring (53 ppm, $58 \mathrm{ppm}){ }^{6}$

In the study of J.Wang et al, the ${ }^{1} \mathrm{H}-\mathrm{NMR}$ spectra of soybean oil showed the proton shift of olefinic $(\mathrm{H}-$ $\mathrm{C}=\mathrm{C}-\mathrm{H})$ at $(5.23 \mathrm{ppm} \div 5.42 \mathrm{ppm})$, which was very low in the ${ }^{1} \mathrm{H}-\mathrm{NMR}$ spectra of soybean epoxidized oil and instead there was a strong the proton shifts of epoxide ring at $(2.86 \mathrm{ppm} \div 3.09 \mathrm{ppm})$. The ${ }^{13} \mathrm{C}$ NMR spectra of soybean oil reported the carbon shift of olefinic $(\mathrm{C}=\mathrm{C})$ reported at $120 \mathrm{ppm}, 130 \mathrm{ppm}$, which did appear in the ${ }^{13} \mathrm{C}$-NMR spectra of soybean epoxidized oil and instead the carbon shifts of epoxide ring appeared at $(53.2 \mathrm{ppm} \div 56.8 \mathrm{ppm}){ }^{3}$

\section{CONCLUSION}

The study was transformed successfully by-product catfish fat into catfish epoxide oil with high chemical activity. The metabolic efficiency was significantly improved using a cavitation reactor. The highest yield $(94.11 \%)$ of catfish fat epoxidation reaction was achieved at $50 \mathrm{PSi}, 45{ }^{\circ} \mathrm{C}$, molar ratio of $\left(\mathrm{H}_{2} \mathrm{O}_{2} / \mathrm{CH}_{3} \mathrm{COOH} /\right.$ unsaturated compounds in fat) of (3.75/1.25/1) in just 5 minutes. The chemical structure of materials and products were determined clearly by the FT-IR, ${ }^{1} \mathrm{H}-\mathrm{NMR},{ }^{13} \mathrm{C}-\mathrm{NMR}$ analysis. It could be said that the synthesis of catfish epoxide oil from catfish fat, performed on the cavitation reactor can develop green chemistry.

\section{ACKNOWLEDGMENT}

This research is funded by Ho Chi Minh City University of Technology (HCMUT), VNU-HCM under grant number BK-SDH -2020-1585017. 


\section{REFERENCES}

1. J. C. J. Bart, E. Gucciardi and S. Cavallaro, 2013, Renewable feedstocks for lubricant production, in: Biolubricants, Woodhead Publishing, Cambridge, pp. 121-226,

2. J. C. J. Bart, E. Gucciardi and S. Cavallaro, 2013, Chemical transformations of renewable lubricant feedstocks, in: Biolubricants, Woodhead Publishing, Cambridge, pp. 249-329,

3. J. Wang, Y. Liu, Z. Zhou, Y. Fu and J. Chang, Industrial \& Engineering Chemistry Research, 56(29), 8224(2017), DOI:10.1021/acs.iecr.7b01677

4. S. Silviana and A. Subagio, Rasayan Journal Chemisrty 12(3), 1470(2019), DOI: $10.31788 /$ RJC.2019.1235240

5. R. Turco, R. Tesser, R. Vitiello, V. Russo, S. Andini and M. D. Serio, Catalysts, 7(309), 1(2017), DOI: $10.3390 /$ catal 7100309

6. R. V. Sharma, A. K. R. Somidi and A. K. Dalai, Journal of Agricultural and Food Chemistry, 63(12), 3235(2015), DOI:10.1021/jf505825

7. A. K. R. Somidi, U. Das and A. K. Dalai, Chemical Engineering Journal, 293 (1), 259(2016), DOI:10.1016/j.cej.2016.02.076

8. K. A. Aissa, J. Zheng, L. Estel and S. Leveneur, Organic Process Research \& Development, 20(5), 948(2016), DOI:10.1021/acs.oprd.6b00040

9. G. L. Maddikeri, P. R. Gogate and A. B. Pandit, Fuel, 137 (1), 285(2014), DOI: 10.1016/j.fuel.2014.08.013

10. S. Mohan, A. Pal and R. Singh, Energy Sources. Part A: Recovery, Utilization, and Environmental Effects, 39(10), 955(2017), DOI:10.1080/15567036.2016.1235059

11. P. Dhanke, N. Kanse, D. Deshpande and S. Wagh, Asian Journal of Convergence in Technology, II(III), 1(2019),

12. L. F. Chuaha, S. Yusupa, A. R. A. Azizb, A. Bokharia, J. J. Klemeš and M. Z. Abdullah, Chemical Engineering and Processing, 95 235(2015), DOI:10.1016/j.cep.2015.06.018

13. T. T. Hong, N. M. Tien, D. Quy-Diem, N. K. Trung, D. T. K. Thoa and P. M. Tan, Rasayan Journal of Chemistry, 12(4), 2058(2019), DOI:10.31788/RJC.2019.1245289

14. I. A. Khan, N. Prasad, A. Pal and A. K. Yadav, Energy Sources, Part A: Recovery, Utilization, and Environmental Effects, 42(20), 2461(2019), DOI:10.1080/15567036.2019.1607946

15. Minister of Vietnam's Agriculture and Rural Development, Approving the planning for farming and processing pangasius in the Mekong Delta until 2020, 356 / QĐ-TTg, Vietnam Ministry of Agriculture and Rural Development, Ha Noi, (2014)

16. T. T. Hong, T. V. Phuoc and P. M. Tan, ARPN Journal of Engineering and Applied Sciences, 13(24), 9707(2018),

17. T. T. Hong, D. T. K. Thoa, N. K. Trung and P. M. Tan, Vietnam Trade and Industry Review, 16, 282(2018).

18. V. B. Borugadda and V. V. Goud, Journal of Bioprocess Engineering and Biorefinery, 3(1), 57(2014), DOI:10.1166/jbeb.2014.1077

19. L. K. Hong, R. M. Yusop, N. Salih and J. Salimon, The Malaysian Journal of Analytical Sciences, 19(1), 144(2015)

20. U. S. Agarwalla, Rasayan Journal of Chemistry, 11(2), 756(2018), DOI: $10.31788 /$ RJC.2018.1123029

21. S. Silviana, D. D. Anggoro and A. C. Kumoro, Rasayan Journal of Chemistry, 12(3), 1360(2019), DOI: $10.31788 /$ RJC.2019.1235190

22. S. Bargole, S. George and V. K. Saharan, Chemical Engineering \& Processing., 139, 1(2019), DOI:10.1016/j.cep.2019.03.012

23. Y. T. Shah, A. B. Pandit and V. S. Moholkar, 1999, Factors Affecting Cavitation Behavior, in: Cavitation Reaction Engineering, Springer Science Business Media, New York, pp. 55-82, DOI: $10.1007 / 978-1-4615-4787-7$

24. P. B. Subhedar and P. R. Gogate, Ultrasonics Sonochemistry, 29, 67(2016), DOI:10.1016/j.ultsonch.2015.09.006

25. A. V. Mohod, P. R. Gogate, G. Viel, P. Firmino, Reinaldo and Giudici, Chemical Engineering Journal, 316 (15), 751(2017), DOI:10.1166/jbeb.2014.1077

[RJC-5926/2020] 